\title{
The effect of uniqueness and student's experience in improving university image: Empirical study
} at private universities in Indonesia

\author{
Asep Muhamad Ramdan ${ }^{\text {a,b* }}$, Agus Rahayu ${ }^{a}$, Lili Adi Wibowo and Puspo Dewi Dirgantari ${ }^{a}$
}

${ }^{a}$ Universitas Pendidikan Indonesia

${ }^{b}$ Universitas Muhammadiyah Sukabumi

\begin{tabular}{|c|c|}
\hline CHRON I CLE & A B S T RACT \\
\hline $\begin{array}{l}\text { Article history: } \\
\text { Received: June } 20,2020 \\
\text { Received in revised format: } \\
\text { August } 302020 \\
\text { Accepted: September } 18,2020 \\
\text { Available online: } \\
\text { September } 23,2020\end{array}$ & $\begin{array}{l}\text { The purpose of this research is to develop a conceptual model to explain the relationship between } \\
\text { the uniqueness of higher education, student experience and university image. Structural Equation } \\
\text { Modeling (SEM) is an analytical technique used to test the model. Data collection is conducted on } \\
268 \text { active students from } 49 \text { private universities in Java West. Research findings report the unique- } \\
\text { ness of tertiary institutions influences student experience; uniqueness of tertiary institutions influ- } \\
\text { ences the image of the University. Moreover, experience of students influences the image of the }\end{array}$ \\
\hline
\end{tabular}

Uniqueness of Higher Education

Student Experience

University Image

\section{Introduction}

Competition in the higher education sector (HE) does not only occur in one country but more than that, HE competition is increasingly global (Lafuente-Ruiz et al., 2018) which occurs as a result of the diminishing role the government in funding at state universities (Kusumawati, 2013). This condition forced HE to market to find sources of funding to finance its operations by offering education services to the public (Faham et al., 2017; Foroudi, 2017; Yu et al., 2019) which ultimately changed the view of HE management from merely an educational service provider to a business institution (Azoury et al., 2014). However, it must be understood that the more universities that are happy, the more similar education services are offered, which in turn will make it harder for universities to win the competition (Panda et al., 2018). In Indonesia, the number of private universities is greater than the number of public universities, based on data from the Ministry of Education and Culture in 2020 recorded from 4,648 universities, as many as $91.5 \%$ or 4,247 are private universities, this results in very tight competition occurring among them to fight for prospective students, but the perception of low quality, high costs, limited study programs offered and the lack of facilities is a problem faced by private universities (Pangarso, 2019). On the other hand, as a result of the government policy on state university autonomy which demands state universities to become more independent, they are competing to show their existence, their greatness and their strengths (Sinatra \& Darmastuti, 2009), making it more difficult for tertiary institutions private sector to obtain prospective students. Seeing the strength of competition, private universities are required to always revitalize their strategies to ensure the suitability of environmental and competitive demands, (Rahayu, 2010), so in the University's image marketing context is the right instrument to win the competition (Foroudi et al., 2019; Lafuente-Ruiz et al., 2018; Panda et al., 2018). Creating the image of a private university is very important for the long-term survival of the university (Plungpongpan et al., 2016), private universities must strive to form a positive image because private universities with a low image will find it difficult to face the challenges of competitive markets (Chen, 2016). Currently private universities have spent funds to build their image (Alkhawaldeh et al., 2020; Azoury et al., 2014), which shows that

* Corresponding author.

E-mail address: asepramdan.upi@gmail.com (A. M. Ramdan) 
university managers are increasingly aware of the importance of imagery (Lafuente-Ruiz et al., 2018), but in reality there was a different view between the intentions of higher education leaders in building an image and people's perceptions who did not always go hand in hand, showing that managing the University's image was not an easy thing (Lafuente-Ruiz et al., 2018). Previous studies have touched on the importance of universities offering curiosity in building images (Curtis et al., 2009; Kusumawati, 2013; Rahim et al., 2009; Panda et al., 2018; Wilkins \& Huisman, 2013), but empirical research on the uniqueness of higher education in building images has not been found. In addition to the uniqueness of higher education, student experience will be a source of increasing University image (Lafuente-Ruiz et al., 2018). Therefore, this study will examine the uniqueness of tertiary institutions and the experience of students in improving their image in tertiary institutions.

\section{Literature Review and Hypothesis Development}

\subsection{Uniqueness of Higher Education}

The uniqueness of higher education is a new construct (novelty) in this study, so it is difficult to find references related to it. Researchers use the concept of distinctive capabilities (DC) which are considered relevant to explain the uniqueness of higher education. As an illustration to understand the concept of distinctive capabilities, the following are several definitions from the authors. According to Kay, (2001) DC as an organization's ability to produce competitive advantages through their uniqueness when competitors cannot easily duplicate, results for a combination of external and internal resources, such as architecture, innovation, and reputation. While Makadok, (2010) defines DC is a valuable capability that explains that an organization is able to do something better than its competitors, referred to as a valuable capability because with its uniqueness the organization is able to process existing resources and develop them into new resources (Helfat, 2002; Riswanto et al., 2019a). Thomas et al. (2018) explain DC is a set of core competencies (resources) used by companies that make companies superior. Not all capabilities inherent in an organization are categorized as unique capabilities, only one or more of them is referred to as the unique capabilities. Meanwhile, according to Barney and Hesterly (2012) unique capabilities have valuable, rare, imitability and are not replaced by other resources (organization). Understanding the definition above, then in this study what is meant by the uniqueness of tertiary institutions is the ability of tertiary institutions to integrate all of the resources possessed both tangible and intangible so as to make the tertiary institution different from other tertiary institutions. Some literature has explained with varying variety of DC indicators in various services, this research attempts to reconstruct indicators that are considered relevant to educational services especially tertiary institutions including the first Marketing Ability (Chumaidiyah, 2011; Palacios-Marqués et al., 2019; Rahim et al., 2009; Simamora, 2016) marketing capabilities in this study include promotional activities and variations in promotion, both Management Capabilities (Rahim et al., 2009; Simamora, 2016) include quality assurance services and institutional accreditation, third Collaboration (Ciptagustia \& Kusnendi, 2019; Kay, 2001) include the ability of tertiary institutions to collaborate with other domestic and foreign tertiary institutions and cooperation with other institutions, the four human resources (Simamora, 2016; Thomas et al., 2018 ) includes the skills of lecturers and staff as well as academic qualifications of lecturers, the five infrastructure (Chumaidiyah, 2011) Thomas et al., 2018) include the completeness of learning support and the quality of Information Systems and E-Learning, the sixth technological innovation (Chumaidiyah, 2011; Ciptagustia \& Kusnendi, 2019; Darsono et al., 2016; Kay, 2001; Rahim et al., 2009; Simamora, 2016) covers patents produced, prototypes and the unique learning curriculum offered.

This study aims to measure the relationship between higher education (distinctive capabilities), Customer Experience (student experience) and Corporate Image (University image). Even though the relationship between DC and corporate image is difficult to find, but in research conducted (Maulidasari, 2016; Mihardjo et al., 2018) have explained that distinctive capabilities have a significant relationship with company image. While the positive relationship between variable distinctive capabilities and customer experience is explained in research (Chheda et al., 2017; Foroudi et al., 2016; Mihardjo et al., 2020).

\section{$\mathrm{H}_{1}$ : The uniqueness of higher education influences student experience.}

$\mathrm{H}_{2}$ : The uniqueness of universities influences the image of the University.

\subsection{Student Experience}

Consumer behaviour researchers use different terms in discussing experiences such as consumption experiences (Bolton et al., 2014), customer experiences (Palmer, 2010), and service experiences (Helkkula, 2011), giving rise to difficulty in understanding and adopting the concept of customer experience into empirical research, but in this study the approach used is customer experience (CE) in the service context. CE is a cognitive, emotional, physical, sensory, and social response caused by market participants (De Keyser et al., 2015; Siqueira et al., 2019) which stem from a series of interactions that occur between customers and products (Riswanto et al., 2019b; Riswanto et al., 2020), companies, or parts of organizations, which trigger reactions (Gentile et al., 2007). This experience is truly personal and implies customer engagement at different levels. $\mathrm{CE}$ is a new level for creating value not only for companies but also for customers and good experience generally has to engage with individuals with varying degrees (Meyer \& Schwager, 2007). Although the concept of experience in the service industry is less developed (Dube \& Helkkula, 2015), CE is at the core of this domain. Customers experience a series of positive or negative clues that help them make an impression. Directions may be performance based or context based. Performance instructions are based on service functions while context instructions are more related to the atmosphere which involves sight, 
sound, touch. A positive customer experience can be obtained by systematically guiding the instructions. Clues also help differentiate experiences. If the instructions are not managed properly, they also give a negative perception (Fatma, 2014). In higher education services, students are often referred to as customers (Royo, 2017; Le Roux \& Van Rensburg, 2014), therefore the concept of CE in this context is a sensation and knowledge of the totality of student interaction with various elements of higher education services that automatically stored in the memory of students' customers (Temple et al., 2014). According to Keiningham et al., (2019), in general there are three basic principles of CE, the first is interactional which means that CE always comes from interactions between customers and companies through various activities both human and non-human (such as technology ) secondly there is a certain level of uniqueness mark every CE. The third of CE is related to its multidimensional nature. Some researchers have contributed various CE dimensions in their research, proposing five dimensions namely Cognitive: What people think, Physical: How people interact, Sensory: What people experience (through their senses), Emotional: How people feel, Social: How people share. Almost the same as Keiningham, (Dziewanowska, 2015) contributed five dimensions in his research Sensory (sensory experiences), Emotional (mood, emotions and feelings), Cognitive (conscious mental processes), Pragmatic (physical activities and utilities), Lifestyle (Lifestyle) values and personal beliefs), Relational (belonging to a community and confirmation of the social identity). Long before them (Lemke et al., 2010) accessibility: ease of interacting and accessing services, competence: provider competence, customer recognition: knowledge of the presence of consumers, helpfulness: ease of asking for help, personalization: treatment of providers, problem solving: problem solving by provider, promise fulfilment: fulfilment of promises by providers, value for time: appreciation of consumer time. Regarding CE in higher education, specifically (Royo, 2017) proposes five dimensions including "the application experiencecovering the interactions between potential students and the institution, up to the point of arrival; the academic experience students' interactions with the institution associated with their studies, excluding for these purposes teaching and learning processes; the campus experience - student life not directly connected with study, which may include activities away from the actual campus (insofar as one exists); the graduate experience - the institution's role is assisting students' transition to employment". Based on the various dimensions above, this study tries to propose dimensions by combining several dimensions into six different dimensions, namely Accessibility of application experience: related to the ease of students when registering, Academic services: Student reactions to academic services, Environment of higher education: Student feelings on the physical environment in supporting academic activities, Student Care: Student's feelings towards the attention given by universities, relation: student ties with universities, Campus Competence: university abilities. Studies conducted by previous research have explained that customer experience has a positive relationship with image, although the research they conducted was not at all in the education service industry (Bacik et al., 2018; Domb et al., 2015; Fatma, 2014; Sirapracha \& Tocquer, 2012).

\section{$\mathrm{H}_{3}$ : Student Experience affects the Image of the University}

\subsection{University Image}

There is no denying that at this time that image has become a strategic key for private tertiary institutions in increasingly competitive conditions (Alkhawaldeh et al., 2020), but nevertheless empiric research related to the University's image as the main source of competitive advantage has not yet been found (Panda et al., 2018). Higher education competes to improve their image to have strong competitiveness, because prospective students pay close attention to the image before deciding to choose a college (Ramdan et al., 2020; Woodall et al., 2014), by therefore university leaders must realize that developing a positive image is more important than creating awareness (Mourad et al., 2011). Researchers have previously studied the University's image from various perspectives by adapting the corporate image approach, so that each has a different interpretation of the University's image, Ivy (2001) describes the University's image as "a function of the strategy used by higher education institutions, how they are implemented, and how they are understood by their public. Arpan et al., (2003) define the University's image as the sum of all beliefs a person has towards a university. Correspondingly, Alessandri et al., (2006) suggested that the University's image is "a public perception of the university. The University's image is also said to be the sum of all beliefs that a person has towards a university (Duarte et al., 2010). A more complete definition of the concept of the University's image was put forward by (Lafuente-Ruiz et al., 2018) namely "as an evaluation carried out by different stakeholders of a university through perceptions, beliefs, ideas, and impressions which as a consequence of consistent expressions from time to time, they have accumulated about it". The organizational image of a university refers to the image perceived by the external public (public and private organizations, graduates, government institutions) and internal public (current students, professors, administrative staff and services, among others), according to their experience, interests and the idea of doing a rational, cognitive and emotional assessment of institutional characteristics and attributes (Wilkins \& Huisman, 2015). The differences between writers about the University's image, showing that the university's image is a multidimensional construct that is difficult to measure (Panda et al., 2018), a literature study conducted by Lafuente of 70 articles, yields one of his conclusions is "there is no consensus regarding the dimensions of the image and reputation of higher education (LafuenteRuiz et al., 2018), but recent research suggests dimensions such as those consisting of university heritage, trustworthiness and service quality (Panda et al., 2018), Symbolic meanings, Accessibility, Quality of service, Academic quality, Tangible elements (Wilkins \& Huisman, 2015), Perception of the academic offer, Perception of graduate training, Perception of cost, Perception of cost massification, Perception of teaching resources, Perception of research resources (Lafuente-Ruiz et al., 2018). 


\section{Method}

This research was conducted at 49 Private Universities in West Java and data were collected from 268 active students as respondents through the distribution of online questionnaires developed from previous literature. The first part of the questionnaire is intended to collect data related to the characteristics of gender respondents, the level of education of the institution's accreditation rank and level of education, in the second part of the questionnaire is intended to measure various constructs related to various components, namely the uniqueness of universities that are based on research (Chumaidiyah, 2011; Ciptagustia \& Kusnendi, 2019; Kay, 2001; Palacios-Marqués et al., 2019; Rahim et al., 2009; Simamora, 2016; Thomas et al., 2018), Student experience with dimensions of Accessibility of application experience, Academic services, Environment of higher education, Student Care, Relation, Campus Competence sourced from research (Royo, 2017; Dziewanowska, 2015; Keiningham et al., 2017; Lemke et al., 2010) university image with indicators sourced from research (Panda et al., 2018) namely university heritage, trustworthiness and service quality. The collected data is then tested in two stages. In the first stage, the measurement model is validated with the help of confirmatory factor analysis (CFA). In the second stage, the structural model is examined to examine the relationship between various variables considered in this study, along with a series of statistical data analysis using the help of SPSS 24 and Amos 24 software.

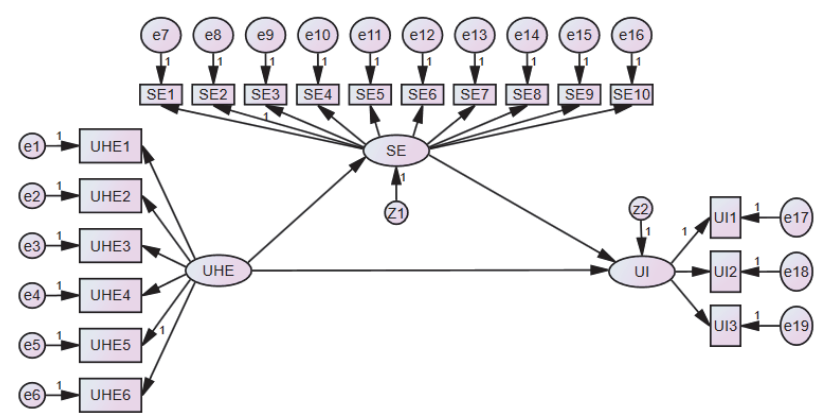

Fig. 1. Full Structural Model Analysis

\section{Result}

Source: Authors' own data processing

Participation of Respondents in this study varied, from 268 students who became respondents $61.9 \%$ or 166 were women while the remaining $38.1 \%$ or 102 men, all respondents came from 47 private universities in West Java which consisted of $11 \%$ or 5 universities have an " $\mathrm{A}$ " accreditation rating, $65 \%$ or 31 universities with a "B" rating and the remaining $24 \%$ or 11 universities have an "C" accreditation rating. Respondents came from various educational programs, data showed $89 \%$ of respondents were from the Undergraduate Program, 3\% were Diploma Programs, 6.3\% were Masters Programs and $1.7 \%$ were from Doctoral Programs $(\mathrm{PhD})$. As explained earlier, this study was conducted with two stages of testing, namely the validation stage and testing the relationship between variables. The results of testing the validation show the results as presented in Table 1.

Table 1

Measurement Validity and Reliability Construct

\begin{tabular}{|c|c|c|c|}
\hline Variable and Indicator & Std. Loading (Value Lamda) & Convergent Validity (AVE) $\geq 0.50$ & Contruct Reliability $(\mathrm{CRI}) \geq 0.70$ \\
\hline \multicolumn{4}{|l|}{ Uniqueness of higher education } \\
\hline UHE 1 & 0.624 & 0.592 & 0.896 \\
\hline UHE 2 & 0.799 & & \\
\hline UHE 3 & 0.808 & & \\
\hline UHE 4 & 0.750 & & \\
\hline UHE 5 & 0.782 & & \\
\hline UHE 6 & 0.836 & & \\
\hline \multicolumn{4}{|l|}{ Student Experience } \\
\hline SE 1 & 0.749 & 0.641 & 0.931 \\
\hline SE 2 & 0.775 & & \\
\hline SE 3 & 0.768 & & \\
\hline SE 4 & 0.757 & & \\
\hline SE 5 & 0.601 & & \\
\hline SE 6 & 0.818 & & \\
\hline SE 7 & 0.805 & & \\
\hline SE 8 & 0.838 & & \\
\hline SE 9 & 0.741 & & \\
\hline SE 10 & 0.789 & & \\
\hline \multicolumn{4}{|l|}{ University Image } \\
\hline UI 1 & 0.848 & 0.750 & 0.900 \\
\hline UI 2 & 0.865 & & \\
\hline UI 3 & 0.762 & & \\
\hline
\end{tabular}


As presented in Table 1 above, it can be explained that all indicators already have lambda values in accordance with the minimum measurement standards of 0.40-0.60 (Beckett et al., 2018) while the results obtained are already above the numbers 0.647-0.865, thus showing their respective contributions - each indicator can be accepted with a good level of significance that is above the critical ratio of 1.96 or 2.0 (Arbuckle, 2016). Analysis of instrument validity was performed using convergent validity (AVE) with a standard $\geq 0.50$ (Beckett et al., 2018), the results showed that all three variables had AVE values that met the measurement standards, namely for each variable of (uniqueness of higher 0.592 , student experience 0.641 and University Image 0,750), meanwhile Measurement reliability construct using the Construct reliability index (CRI) with a standard $\geq 0.70$ measurement results showed a good level of reliability namely (uniqueness of higher 0.896 , student experience 0.931 and University Image 0.900). Furthermore, to examine the relationship between variables, using the complete SEM, the empirical model proposed by Uniqueness of higher education as an exogenous variable while student experience and University Image as endogenous variables, after testing the results show that the model required is very feasible as shown by the value of CMIN test results (1.94) is good, GFI 0.912 is good, CFI (0.966) is good, TLI (0.957) is good and RMSEA (0.060). In addition, based on the results of hypothesis testing it can be seen that all hypotheses can be accepted because the CR value of 1.96 and the value of P-value, 0.005 .

Table 2

\begin{tabular}{|c|c|c|c|c|c|c|}
\hline The Hypothesized Relationship & Std. Estimate & Estimate & S.E & C.R & $\mathrm{P}$ & Conclusion \\
\hline $\mathrm{SE} \leftarrow U H E$ & 0.750 & 0.767 & 0.066 & 11.698 & $* * *$ & Supported \\
\hline $\mathrm{UI} \leftarrow \mathrm{UHE}$ & 0.315 & 0.343 & 0.075 & 4.773 & $* * *$ & Supported \\
\hline \multirow[t]{2}{*}{$\mathrm{UI} \leftarrow \mathrm{SE}$} & 0.561 & 0.597 & 0.084 & 7.077 & $* * *$ & Supported \\
\hline & Goodness-of-fit & & & & Cut off Value & Result \\
\hline Chi-square & & & & & - & 259.172 \\
\hline Degree of freedom & & & & & - & 133 \\
\hline Significance & & & & & $\geq 0,05$ & 0,000 \\
\hline CMIN & & & & & $<3$ & 1.94 \\
\hline GFI & & & & & $\geq 0,90$ & 0.912 \\
\hline AGFI & & & & & $\geq 0,90$ & 0.875 \\
\hline CFI & & & & & $\geq 0,90$ & 0.966 \\
\hline TLI & & & & & $\geq 0,90$ & 0.957 \\
\hline RMSEA & & & & & $\leq 0.08$ & 0.060 \\
\hline
\end{tabular}

\section{Discussion}

The findings in this study resulted from H1 testing which explains that the positive influence of uniqueness of tertiary institutions can be an antecedent in shaping student experience, meaning that tertiary institutions must utilize marketing skills, collaborative capabilities, resources, infrastructure and technological innovations so as to increase sensation or good knowledge that effectively will automatically be stored in the memory of students, these findings support previous research conducted by Chheda et al., (2017) Foroudi et al., (2016) and Mihardjo et al., (2020). Referring to the results of hypothesis testing in table 2, the research findings of the $\mathrm{H} 2$ test result explain that the uniqueness of universities can improve the image of the University, this is in line with research conducted by Maulidasari, (2016) and Mihardjo et al., (2018), this study shows that the uniqueness of higher education becomes an antecedent in improving the image of the University, in the university contacts unique sources are obtained from the first Marketing Ability, universities need to increase their activities and variations in promotion, secondly the ability of College Management high need to always maintain the quality of service and institutional accreditation, thirdly the ability of the four human resources include the skills of lecturers and staff and academic qualifications of lecturers, the fifth infrastructure related to the completeness of learning support and the quality of Information Systems and E-Learning, the six technological innovations include patents produced, prototypes and the uniqueness of the learning curriculum offered. Besides that, other important findings are that this study successfully empirically proved statements from previous researchers (Curtis et al., 2009; Kusumawati, 2013; Rahim et al., 2009; Panda et al., 2018; Wilkins \& Huisman, 2013), regarding the importance of universities creating uniqueness as a source of enhancing the University's image. Furthermore, tertiary institutions need to manage student experience well, student experience starts from the ease of students when registering, the academic service process, the physical environment that supports academic activities, the attention of tertiary institutions to students, student ties with tertiary institutions and the ability of tertiary institutions in providing education. Ultimately forming a positive image about higher education, this has been proven through $\mathrm{H} 3$ testing in this study which shows that student experience has a significant positive effect on the image of the research University in line with research conducted by Bacik et al., (2018), Domb et al., (2015); Fatma (2014) and Sirapracha \& Tocquer (2012).

\section{Conclusion}

The research findings conclude that the uniqueness of the university significantly influences the experience of students, the subsequent findings of the uniqueness of the university legally and convincingly can affect the image of the University, this finding is empirical evidence from previous research suggestions. The final finding is that students' experiences can shape the University's image. Based on these findings, the manager of the tertiary institution can implement the indicators in this study 
as an effort to shape the uniqueness of the tertiary institution, the experience of students which ultimately leads to the formation of the image of the University. Finally, theoretically this research contribution enriches marketing management literature specifically marketing for tertiary institutions, practically this research can be a guide for university managers in improving their image through the uniqueness of tertiary institutions and student experience.

\section{Limitation and Future Research}

Actually this study was conducted with good preparation, but still has some limitations, first is because the scope of the analysis unit in this study is limited to private universities so that it cannot be generalized to all types of universities, future research can test models with types of universities more variations so that the model can really be generalized to all types of tertiary institutions. Both of these studies were carried out only in one province so that they have a weakness to be generalized to all existing regions, because it is very open to test this model in a wider area.

\section{References}

Alessandri, S. W., Yang, S. U., \& Kinsey, D. F. (2006). An Integrative Approach to University Visual Identity and Reputation. Corporate Reputation Review, 9(4), 258-270.

Alkhawaldeh, A., Alsaad, A., Taamneh, A., \& Alhawamdeh, H. (2020). Examining antecedents and consequences of university brand image. Management Science Letters, 10(5), 953-960.

Arbuckle, J. L. (2016). IBM® SPSS ${ }^{\circledR}$ User's Guide Amos ${ }^{\mathrm{TM}} 24,1-720$.

Arpan, L. M., Raney, A. A., \& Zivnuska, S. (2003). A cognitive approach to understanding university image. Corporate Communications: An International Journal, 8(2), 97-113.

Azoury, N., Daou, L., \& Khoury, C. EL. (2014). University image and its relationship to student satisfaction- case of the Middle Eastern private business schools. International Strategic Management Review, 2(1), 1-8.

Beckett, C., Eriksson, L., Johansson, E., \& Wikström, C. (2018). Multivariate Data Analysis (MVDA). Book Chapter,

Bacik, R., Fedorko, R., Nastisin, L., \& Gavurova, B. (2018). Factors of communication mix on social media and their role in forming customer experience and brand image. Management and Marketing, 13(3), 1108-1118.

Barney, J. B., \& Hesterly, W. S. (2012). Strategic Manajemen and Competitive Advantage concept (4th ed.). New Delhi: Pearson Education Inc.

Bolton, R. N., Gustafsson, A., McColl-Kennedy, J., Sirianni, N. J., \& Tse, D. K. (2014). Small details that make big differences: A radical approach to consumption experience as a firm's differentiating strategy. Journal of Service Management, 25(2), 253-274.

Chen, C.-T. (2016). The Investigation on Brand Image of University Education and Students' Word-of-Mouth Behavior. Higher Education Studies, 6(4), 23.

Chheda, S., Duncan, E., \& Roggenhofer, S. (2017). Putting customer experience at the heart of next-generation operating models. McKinsey Quarterly, 21, 1-10.

Chumaidiyah, E. (2011). Theoretical Framework: The Influence of Core Technical Competence and Core Marketing Competence to Competitive Advantage. Proceedings of the 2011 International Conference on Industrial Engineering and Operations Management, 1233-1239.

Ciptagustia, A., \& Kusnendi, K. (2019). Distinctive Capabilities: Can it be a source of competitive advantage?, (September). https://doi.org/10.2991/icebef-18.2019.24

Curtis, T., Abratt, R., \& Minor, W. (2009). Corporate brand management in higher education: The case of ERAU. Journal of Product and Brand Management, 18(6), 404-413.

Darsono, N., Yahya, A., \& Amalia, R. (2016). Analysis of Distinctive Capabilities and Competitive Advantage on Business Performance of Tourism Industry in Aceh. Journal of Economics, Business and Management, 4(3), 231-234.

De Keyser, A., Lemon, K. N., Klaus, P., \& Keiningham, T. L. (2015). A Framework for Understanding and Managing the Customer Experience. Marketing Science Institute Working Paper Series 2015, Report No. 15-121, Forthcoming, (Report No. 15-121), 1-47.

Domb, M., Sujata, J., Sanjay, B., Arindam, R., \& Jypti, S. (2016). An empirical study to measure customer experience for telecom operators in indian telecom industry. GSTF Journal on Business Review $(G B R), 4(2)$.

Duarte, P. O., Alves, H. B., \& Raposo, M. B. (2010). Understanding university image: A structural equation model approach. International Review on Public and Nonprofit Marketing, 7(1), 21-36.

Dube, A., \& Helkkula, A. (2015). Service experiences beyond the direct use: indirect customer use experiences of smartphone apps. Journal of Service Management, 26(lss 2).

Faham, E., Rezvanfar, A., Movahed Mohammadi, S. H., \& Rajabi Nohooji, M. (2017). Using system dynamics to develop education for sustainable development in higher education with the emphasis on the sustainability competencies of students. Technological Forecasting and Social Change, 123, 307-326.

Fatma, S. (2014). Antecedents and Consequences of Customer Experience Management-A Literature Review and Research Agenda. International Journal of Business and Commerce, 3(6), 32-49.

Foroudi, P., Jin, Z., Gupta, S., Melewar, T. C., \& Foroudi, M. M. (2016). Influence of innovation capability and customer experience on reputation and loyalty. Journal of Business Research, 69(11), 4882-4889.

Foroudi, P., Yu, Q., Gupta, S., \& Foroudi, M. M. (2019). Enhancing university brand image and reputation through customer 
value co-creation behaviour. Technological Forecasting and Social Change, 138(May 2017), 218-227.

Gentile, C., Milano, P., Noci, G., \& Milano, P. (2007). How to Sustain the Customer Experience : An Overview of Experience Components that Co-create Value With the Customer, 25(5), 395-410.

Helfat, C. E. (2002). The birth of capabilities: market entry and the importance of pre-history. Industrial and Corporate Change, 11(4), 725-760.

Helkkula, A. (2011). Characterising the concept of service experience. Journal of Service Management, 22(3), 367-389.

Ivy, J. (2001). Higher education institution image: A correspondence analysis approach. International Journal of Educational Management, 15(6), 276-282.

Royo J. P., (2017). Students as customers: a paradigm shift in higher education. Annual Review. Debats. Revista de Cultura, Poder i Societat, 2, 151-162.

Dziewanowska, K., (2015). Dimensions of Real and Virtual Consumer Experiences Faculty of Management Working Paper Series 9 ( 4 ) 2015 UW Faculty of Management Dimensions of Real and Virtual Consumer Experiences, 9(NOVEMBER), $1-55$.

Kay, J. (2001). Foundation of Corporate Success: How Business Strategues Add Value. UK: Oxford University Press.

Keiningham, T., Aksoy, L., Bruce, H. L., Cadet, F., Clennell, N., Hodgkinson, I. R., \& Kearney, T. (2019). Customer experience driven business model innovation. Journal of Business Research, (August), 0-1.

Keiningham, T., Ball, J., Benoit, S., Bruce, H. L., Buoye, A., Dzenkovska, J., ... \& Zaki, M. (2017). The interplay of customer experience and commitment. Journal of Services Marketing, 31(2), 1-72.

Kusumawati, A. (2013). A Qualitative Study of the Factors Influencing Student Choice: The Case of Public University in Indonesia. J. Basic. Appl. Sci. Res, 3(1), 314-327.

Lafuente-Ruiz-de-Sabando, A., Forcada, J., \& Zorrrrillallalla, P. (2018). The university image: A model of overall image and stakeholder perspectives. Cuadernos de Gestion, 19(1), 63-86.

Lafuente-Ruiz-de-Sabando, A., Zorrilla, P., \& Forcada, J. (2018). A review of higher education image and reputation literature: Knowledge gaps and a research agenda. European Research on Management and Business Economics, 24(1), $8-16$.

Le Roux, A., \& Van Rensburg, R. J. (2014). Student perceptions of customer experience in a higher education environment. Acta Commercii, 14(1), 1-9.

Lemke, F., Clark, M., \& Wilson, H. (2010). Customer experience quality: An exploration in business and consumer contexts using repertory grid technique. Journal of the Academy of Marketing Science, 39(6), 846-869.

Makadok, R. (2010). The interaction effect of rivalry restraint and competitive advantage on profit: Why the whole is less than the sum of the parts. Management Science, 56(2), 356-372.

Maulidasari, C. D. (2016). Pengaruh Distinctive Capabilities Pengaruh Distinctive Capabilities dan Integrated Marketing Communication Terhadap Citra Destinasi Wisata Maritim Pulau Weh, 2(1), 52-64.

Meyer, C., \& Schwager, A. (2007). Understanding customer experience. Harvard Business Review, 85, 2, p.116.

Mihardjo, Leonardus W.W., Elidjen, Alamsjah, F., \& Sasmoko. (2018). The role of corporate reputation \& distinctive organization capability in developing business model innovation: Case study of indonesian ict firms in facing industry resolution 4.0. Opcion, 34(86), 2190-2208.

Mihardjo, L., Sasmoko, S., Alamsyah, F., \& Elidjen, E. (2020). Maximising co-creation strategy through integration of distinctive capabilities and customer experiences in supply chain management. Uncertain Supply Chain Management, $8(1), 187-196$

Mourad, M., Ennew, C., \& Kortam, W. (2011). Brand equity in higher education. Marketing Intelligence \& Planning, 29(4), 403-420.

Palacios-Marqués, D., García, M. G., Sánchez, M. M., \& Mari, M. P. A. (2019). Social entrepreneurship and organizational performance: A study of the mediating role of distinctive competencies in marketing. Journal of Business Research, 101(February), 426-432.

Palmer, A. (2010). Customer experience management : a critical review of an emerging idea.

Panda, S., Pandey, S. C., Bennett, A., \& Tian, X. (2018). University brand image as competitive advantage: a two country study. International Journal of Educational Management.

Pangarso, A. (2019). Bagaimana meningkatkan kualitas universitas swasta, tempat mayoritas mahasiswa Indonesia kuliah.

Plungpongpan, J., Tiangsoongnern, L., \& Speece, M. (2016). International Journal of Educational Management University social responsibility and brand image of private universities in Bangkok. International Journal of Educational Management, 30(4), 571-59110.

Rahayu, A. (2010). Analisis Sumber Daya Sekolah dan Program Penciptaan Nilai dalam Meningkatkan Daya Saing Sekolah. Educationist, IV(1), 48-56.

Rahim, A., Bakar, A., Hashim, F., \& Ahmad, H. (2009). Distinctive Capabilities and Strategic Thrusts of Malaysia's Institutions of Higher Learning. International Journal of Marketing Studies, 1(2), 158-164.

Ramdan, A. M., Rahayu, A., Hurriyati, R., \& Sultan, M. A. (2020). the role of brand equity in making decisions to choose higher education for new middle-class students. In R. Hurriyati, B. Tjahjono, I. Yamamoto, A. Rahayu, ade G. Abdullah, \& ari arifin Danuwijaya (Eds.), Advances in Business, Management and Entrepreneurship: Proceedings of the 3rd Global Conference on Business Management \& Entrepreneurship (GC-BME 3) (pp. 25-27). London: crc press taylor \& francis group.

Riswanto, A., Hurriyati, R., Wibowo, L. A., \& Gaffar, V. (2019a). Effect of Market Orientation on Business Performance in 
MSMEs as mediating by Dynamic Marketing Capabilities. Calitatea, 20(172), 78-83.

Riswanto, A., Hurriyati, R., Wibowo, L. A., \& Gaffar, V. (2019b). Empirical Assessment of the Role of Product Innovation in Dynamic Marketing Capabilities and Company Performance. Quality-Access to Success, 20(173), 64-67.

Riswanto, A., Rasto, R., Hendrayati, H., Saparudin, M., Abidin, A. Z., \& Eka, A. P. B. (2020). The role of innovativenessbased market orientation on marketing performance of small and medium-sized enterprises in a developing country. Management Science Letters, 1947-1952.

Simamora, V. (2016). Pengaruh keunikan kapabilitas dan turbulensi lingkungan terhadap strategi korporasi dan dampaknya pada kinerja universitas. Journal of Business Studies, 2(1).

Sinatra, L., \& Darmastuti, R. (2009). Kajian Peran Public Relations Dalam Meningkatkan Citra Perguruan Tinggi Swasta Di Jawa Tengah. Scriptura, 2(2), 95-105.

Siqueira, J. R., Peña, N. G., ter Horst, E., \& Molina, G. (2019). Spreading the Word: How Customer Experience in a Traditional Retail Setting Influences Consumer Traditional and Electronic Word-of-mouth Intention. Electronic Commerce Research and Applications, 37(40), 100870.

Sirapracha, J., \& Tocquer, G. (2012). Customer Experience, Brand Image and Customer Loyalty in Telecommunication Services. International Conference on Economics Business and Marketing Management, 29, 112-117.

Temple, P., Callender, C., Grove, L., \& Kersh, N. (2014). Managing the student experience in a shifting higher education landscape, (November).

Thomas, L. Wheelen, Hunger, J. D., Hoffman, A. N., \& Bamford, C. E. (2018). Strategic Management and Business Policy GLOBALIZATION, INNOVATION, AND SUSTAINABILITY FIFTEENTH EDITION GLOBAL EDITION (FIFTEENTH). United Kingdom: Pearson Education Limited.

Wilkins, S., \& Huisman, J. (2013). Student Evaluation of University Image Attractiveness and Its Impact on Student Attachment to International Branch Campuses. Journal of Studies in International Education, 17(5), 607-623.

Wilkins, S., \& Huisman, J. (2015). Factors affecting university image formation among prospective higher education students: the case of international branch campuses. Studies in Higher Education, 40(7), 1256-1272.

Woodall, T., Hiller, A., \& Resnick, S. (2014). Making sense of higher education: Students as consumers and the value of the university experience. Studies in Higher Education, 39(1), 48-67.

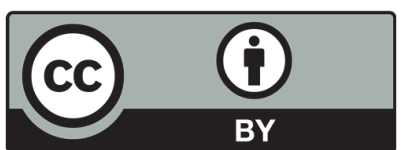

(C) 2020 by the authors; licensee Growing Science, Canada. This is an open access article distributed under the terms and conditions of the Creative Commons Attribution (CC-BY) license (http://creativecommons.org/licenses/by/4.0/). 